\title{
INTERMEDIATE BRONZE AGE IN SOUTHERN LEVANT (4200-4000 BP) - WHY DID FOUR CITIES IN TRANSJORDAN SURVIVE URBAN COLLAPSE?
}

\begin{abstract}
Michał E. Bieniada
Institute of Archaeology, University of Cardinal Stefan Wyszyński, Warsaw, Poland; e-mail:m.bieniada@uksw.edu.pl

Abstract

The first urban culture of southern Levant collapsed and the first period of urbanisation of Canaan (Early Bronze Age I-III) terminated at around $4200 \mathrm{yrs}$ BP. The Canaanites abandoned their walled cities, dispersed and underwent pastoralisation. However, the urban centres of southern Canaan were not destroyed. This fact may point to responsibility of the environmental factor and makes influence influence of anthropogenic factors uncertain, along with the most popular Amorite invasion/destruction hypothesis. A tremendous climatic change occurred at that time in many regions, affecting cultures and civilisations of the Ancient Near East and resulting in abandonment of cities, migrations and great civilizational changes. In southern Levant, virtually all cities were left in ruins with a mysterious exception in Transjordan where four cities: Aroer, Ader, Khirbet Iskander and Iktanu survived and existed throughout the period. Most probably when climatic conditions in Cisjordan excluded possibility of urban life, the ones in Transjordan conditions remained unchanged or altered in a very limited scale. It is now clear that after a period with quite humid and warm climate, the precipitation greatly diminished after $4200 \mathrm{yrs}$ BP in a littoral zone of eastern Mediterranean. A part of Transjordan, probably due to presence of the Dead Sea that somehow created conditions that influenced precipitation, remained a climatic niche with decent rainfall that enabled concentration of population in and around big urban centres and continuation of urban civilisation. Warming in a littoral zone changed dew point temperature preventing formations of clouds above western slopes of Judean and Samarian Hills. Moist air, prevented from condensation was transported eastwards where it could reach ascending currents appearing over the Dead Sea. Masses of air with water vapour moving upwards could form rainy clouds in Transjordan.
\end{abstract}

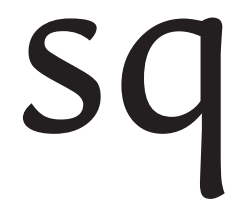

Key words: Palestine 4200 BP; collapse of urbanism, Intermediate Bronze Age; climatic niche in Transjordan; influence of Dead Sea.

Manuscript received 24 September 2015, accepted 26 February 2016

\section{APPLICATION OF PALAEOCLIMATOLO- GICAL RECONSTRUCTION TO HISTORICAL EVENTS, SOME REMARKS}

Climate is not a constant issue and it keeps changing, due to cosmic and planetary factors. The climate fluctuations have been repeated in the past (Bond et al., 1997) and greatly influenced the Earth's biosphere. They affected ancient cultures and civilisations as well, among others a sudden aridification had negative impact in North Africa, Middle East and Asia (Weiss 2012). It caused a collapse of the Akkadian Empire (Weiss et al., 1993; deMenocal 2001) and Egypt (Stanley et al., 2003; Welc, Marks 2013, 2014).

There are many sophisticated methods to study past climatic changes, especially in the Holocene (e.g. Berglung and Ralska-Jasiewiczowa, 2003). Yet, when it comes to the issue of applying it to historic developments two basic problems emerge. Firstly, influence of any climatic change on ancient civilisations does not have predictable reflection since humans as skilful and problem-solving species often try to find a reasonable solution in the face of danger. In fact, it does not seem obvious that for example, a development of irrigation in Mesopotamia was an effect of climate change or it was caused by humans in response to larger and more concentrated population. Secondly, complexity of successive reaction processes in case of climate change and human reaction and adaptation greatly limits our chances to explain them univocally and there are also problems with dating of climate events in the past.

The so-called Bond events are repeating periods in climate change, which occur every $1470 \pm 500$ years (Bond, et $a l ., 1997)$. Two of them occurred when the first civilisations widespread in the Ancient Near East. The 5.9 kyrs (3900 $\mathrm{BCE}$ ) event terminated the Neolithic subpluvial in this region (Brooks, 2006). The Ubaid culture in Mesopotamia declined and a large area has been aridified. Combined with the Holo- 


\begin{tabular}{|c|c|c|}
\hline Egypt & Palestine & Mesopotamia \\
\hline & & $\begin{array}{l}\text { Ubaid Culture } \\
5300-3800 \\
\text { Uruk Period } \\
3800-3100\end{array}$ \\
\hline Early Dynastic Period & & \\
\hline $3000-2700$ & & $\begin{array}{l}\text { Jemdet Nasr Culture } \\
3100-2900\end{array}$ \\
\hline Old Kingdom & Early Bronze Age & \\
\hline $2700-2200$ & $3200-2200$ & $\begin{array}{l}\text { Early Dynastic Period } \\
2900-2350\end{array}$ \\
\hline First Intermediate period & Intermediate Bronze Age & Akkadian Period \\
\hline $2200-2000$ & $2200-2000$ & $2350-2150$ \\
\hline Middle Kingdom & Middle Bronze IIA & Ur III Period \\
\hline $2100-1800$ & $2000-1800$ & $\begin{array}{l}2100-2000 \\
\text { Isin-Larsa (and Old Assyrian) periods } \\
2000-1800\end{array}$ \\
\hline $\begin{array}{l}\text { Second Intermediate period } \\
1800-1550\end{array}$ & $\begin{array}{l}\text { Middle Bronze IIB-C } \\
1800-1550\end{array}$ & $\begin{array}{l}\text { Old Babylonian Period } \\
1800-1600\end{array}$ \\
\hline
\end{tabular}

Fig. 1. Chronological correlation between Egypt (Shaw, 2000), Palestine (Stern, 1993) and Mesopotamia (Kuhrt, 1995); all ages BCE, the ages roughly rounded up.

cene marine transgression, the civilisation centre was forced to be shifted southwards to Sumer, but also irrigation techniques developed and population was centralized (Kennett and Kennett, 2007). Yet, the cultural developments in Mesopotamia have not been under a dramatic stress. The Ubaid culture was replaced by a dawn of the urban civilisation of the Uruk period (Fig. 1; e.g. Rothman, 2001). It is equally justified to explain civilization changes (concentration of population in big river valleys) by climatic or human factors. Growth of population exceeding carrying capacity of the ecosystem might have created a challenge, which led to invention of irrigation, but technical development and new agricultural technology simply required concentration of people. The development might be understood as an example of Malthusian trap and Boserupian response (Malthus, 1826; Boserup, 1965).

The 4.2 kyrs (2200 BCE) crisis was one of the most fateful Bond events and it was responsible for the collapse of the Akkadian Empire and the end of the Egyptian Old Kingdom (deMenocal, 2000; Welc and Marks, 2014). The Akkadian Empire collapsed around 2150 yrs BCE. The invasion of Amorites from the north and of Guteans (who ruled Mesopotamia for about a century) could be another reason. However, around 2113 yrs BCE Utu-Hegal expelled Guteans and soon the Sumerian Renaissance (UR III Period) began (e.g. van de Mieroop, 2007). It is Ur III, a collapse of which (2006 yrs $\mathrm{BCE}$ ) is often explained as caused by climatic factors result- ing in famine and soil-salinisation, because at the end of Ur III period barley which is more resistant to salinisation, replaced wheat as the main cereal (Redman, 1999). Migration of Amorites, enemies from Elam and Shimmashki had their impact too. Yet, this was merely a collapse of a ruling dynasty (system created by the Akkadian kings), but not a disintegration of the urban life. In fact, Ur III has continued in sense of a socio-political mechanism in the Isin-Larsa Period.

There are problematic issues that make results of any studies aimed at defining influence of climatic shifts on ancient cultures unequivocal and disputable. First, the margin of chronological error of dating any climatic changes is much wider than that which is acceptable in archaeology. In addition, a time span between a climate change and cultural response is unknown; therefore we do not know a delay in each case. A process of action-reaction between climate change and cultural response may resemble a domino effect. Some climatic episodes may also affect cultures indirectly and with some delay bringing for example waves of migrations from a territory affected by climate change (which was probably the case of Amorite invasion in Akkadian and Ur III periods). Along with natural reasons, there is also human impact - people change environment as well, over-flooding in agriculture based mainly on intensive irrigation effects in increased salinity of soils (e.g. Pitman and Läuchli, 2002). Deforestation and herding may be another reason for aridification. 
Another problem is of methodological character - we cannot precisely define the range of any climatic change impact - it is a far going generalisation to assume that climate change always gives the same effect everywhere. Regional variations and characteristic features in sub-regions should be also taken under consideration. In other words, a climate change can bring different effects in different areas. Even if a climate change (usually expressed by change of precipitation and temperature) are correctly defined, it is difficult or impossible to establish its final impact in some regions. As noted elsewhere (Bouzek, 1982), a climate change may bring both positive and negative effects. Orni and Efrat (1980) quoted an example when potentially positive change in precipitation (more rain) may lead to worsening of vegetation conditions. In areas with thick soil with considerably large capacity of accumulation of water, higher precipitation usually improves fertility and makes a vegetation period longer. On the other hand, in semi-desert areas more precipitation may cause opposite effect, resulting in salinisation and impoverishment of a soil.

\subsection{KYRS CLIMATIC EVENT AND ITS POSSIBLE IMPACT ON SETTLEMENT PATTERN IN SOUTHERN LEVANT}

"The large fields and acres produced no grain

The flooded fields produced no fish

The watered gardens produced no honey and wine

The heavy clouds did not rain

On its plains where grew fine plants

'lamentation reeds' now grow."

The Curse of Akkad, ca. 2100 BCE

An analysis of the Dead Sea sediments (Neev and Emery, 1967) as well as a thorough research conducted in the Soreq Cave near the Dead Sea (Bar-Matthews and Ayalon, 2011) proved that the climate dried abruptly ca. 4200 yrs BP (Fig. 2; Bar-Matthews and Ayalon, 2011). The level of the Dead Sea was relatively high in the Early Bronze Age I-III (first urban period) and it dropped drastically in 2100-1800 yrs BCE. Drying of the Dead Sea was due to a climate change: there was less water in the Jordan River and its tributaries (Frumkin and Elitzur, 2001).

The change had tremendous impact on ancient cultures in Transjordan. Shortage of water diminished considerably a carrying capacity of the ecosystem in southern Levant causing settlement decentralisation. It was not possible to maintain traditional model of settlements with dense urban centres in poor environmental conditions (for similar situation in the Early Iron Age in Palestine see: Bieniada, 2006). In effect, the towns in the Mediterranean littoral zone were deserted and changed into ruins. Traditionally agricultural and rich-soil regions lost their potential and were abandoned (Dever, 1995). The only strategy of survival suitable in new circumstances included dispersion of population, change to herding and little farming (with less demanding sheep and goats) and migration in search for seasonal pastures to exploit a poor environment in optimal way. Archaeological excavations prove that urban life (i.e. existence of centralized popula-

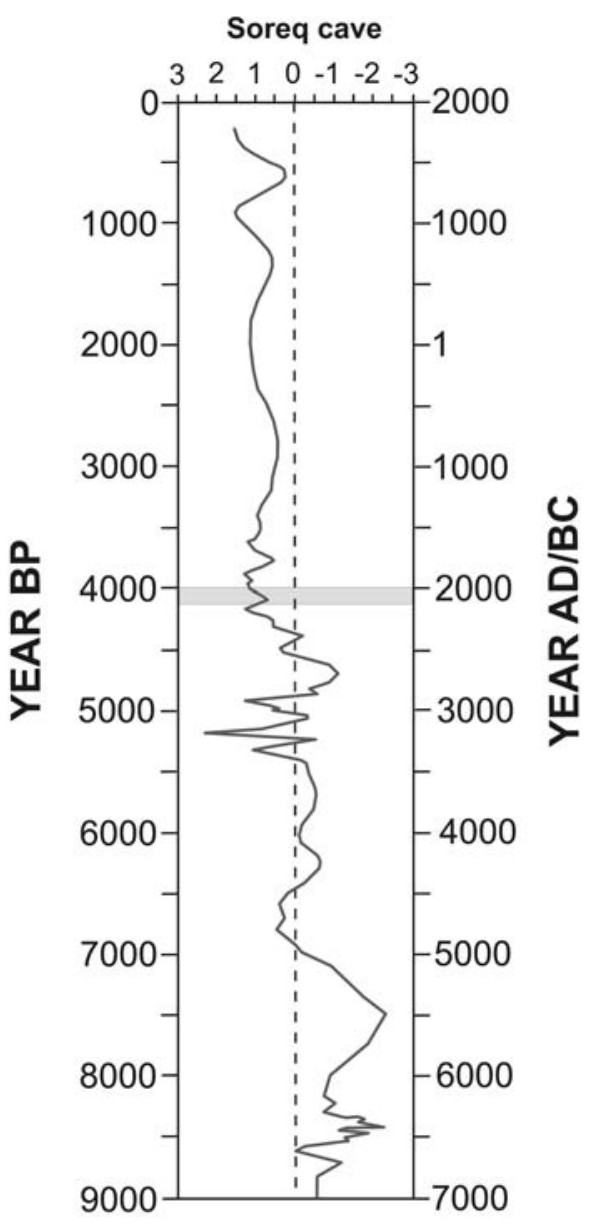

Fig. 2. Standardised normal $\delta^{18} \mathrm{O}$, records from the Soreq Cave in Israel after Bar-Matthews et al. (1997).

tions) in Cisjordan was impossible for more than two centuries (Richard, 1987). Decomposition of social and political structures of the Early Bronze Age urban Canaan was so deep and profound that some scholars refer to the subsequent period (Early Bronze Age IV or Intermediate Bronze Age) as the retreat to Neolithic subsistence mode of economy and to chiefdom model in a socio-political term (Richard, 1987).

In southern Levant a climate change which occurred in the Intermediate Bronze Age caused total abandonment of the towns in the Mediterranean zone (for example: Dan, Tell Beit Mirsim, Megiddo, Ta ${ }^{c}$ anach, Lachish, Tell Arad: Fig. 3), dispersion of population and pastoralisation (Dever, 1995). However, at the same time four towns continued to flourish in Transjordan (Laughlin, 2000; Issar and Zohar, 2007). They were Khirbet Iskander (Parr, 1960; Richard, 1986), Aroer (Olávarri, 1969), Ader (Cleveland, 1960) and Iktanu (Prag, 1974). Apparently, for some reason the centre of development during the EB IV (Intermediate Bronze Age) period was to the east of the Jordan River (Bárta, 2010).

\section{TRANSJORDAN AS AN EXCEPTION DUE TO INFLUENCE OF THE DEAD SEA?}

An outstanding exception is the fact that while west of the Jordan River all towns have disappeared, the urban life 


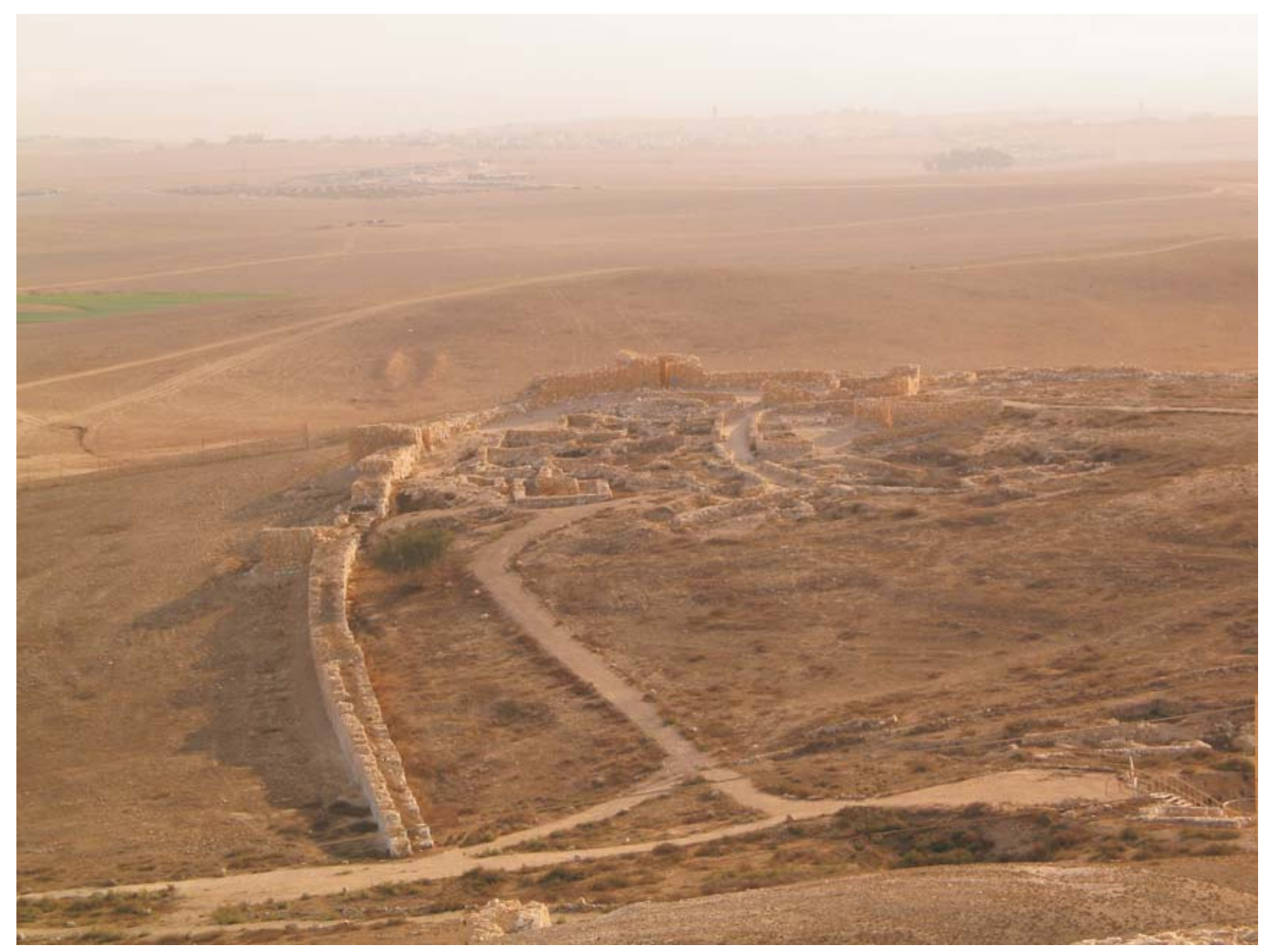

Fig. 3. Tell Arad, View on city fortifications dated to Early Bronze III age, abandoned at the end of EB III period.

continued in some areas of Transjordan. The archaeological research proved that at least four urban centres still existed and flourished east of the Jordan River. According to the dated bone finds, people had enough fodder to keep cattle and pigs in addition to sheep and goat (Gophna, 1992). Climatic conditions there have not changed much apparently and they were good enough to maintain traditional centralization of considerably large populations in and around walled towns, where a culture of the Early Bronze Age Canaan continued. Three of four towns are located at an edge of the present isohyet $250 \mathrm{~mm}$ (Fig. 2), a theoretical border of rain farming. The southernmost Khirbet Ader (Khirbet - in Arabian ruin) is located on Wadi Adir, a perennial stream, Araer (Aroer) is on the Arnon River, Khirbet Iskander is located in a valley surrounded by hills, which is a rich agricultural region at present. Iktanu, the only one was not located in a well-watered lowland - people who lived there acquired water in another way (Finlayson et al., 2011).

A part of Transjordan became a civilization niche where urban culture survived. Despite aridification to the west of the Jordan River as an effect of a climate change during the Bond 3 event (on increasing aridity during Bond 3 event see: Walker 2012 et al. and references here in), some peculiar weather conditions could result in continued precipitation high enough to preserve a traditional way of life.

In southern Levant, before the Bond 3 event most moisture, as it is today was transported from the west (Goldreich, 2003). The air was heated over seashore and raised high enough to take water vapour up to form clouds and produce rain in a littoral zone. This pattern is characteristic for Mediterranean climate today - in Israel, most rainfalls occur in spring between the Mediterranean seashore and slopes of Judean and Samaria Hills (Orni and Efrat, 1980). The Bond 3 event, which effected in overall a temperature rise could have disturbed such usual circulation and caused cessation of rains.

Today, western winds, which carry moisture from the Mediterranean Sea, when reaching shores of the southern Levant, meet with warm air ascending over the land. Water vapour is raised to the dew point where it turns into rain clouds. Mountains of Judea and Samaria form a barrier parallel to a seashore where moist air is cooled and condensed into rain. In effect, only a part of moist air reaches Transjordan.

The climate change connected with the Bond 3 event might have changed air temperature and amount of atmospheric moisture, which in turn affected in alteration of a dew point as well as dew point temperature and caused that rain clouds have not formed in a littoral zone. Moist air was transported by winds eastwards, over the Judean and the Samarian Mountains (both below $1000 \mathrm{~m}$ a.s.1.). Clouds could have formed much further from a sea - in Transjordan where the air containing the Mediterranean water vapour was moved by hot ascending currents appearing over a hot area of the Dead Sea high enough to form clouds and condense into rain. In effect, rainfalls moved from a seashore eastwards making part of Transjordan a niche where precipitation remained on a decent level enabling sedentary and centralised settlement. However, this hypothesis still requires further studies and creation of suitable climate models. 


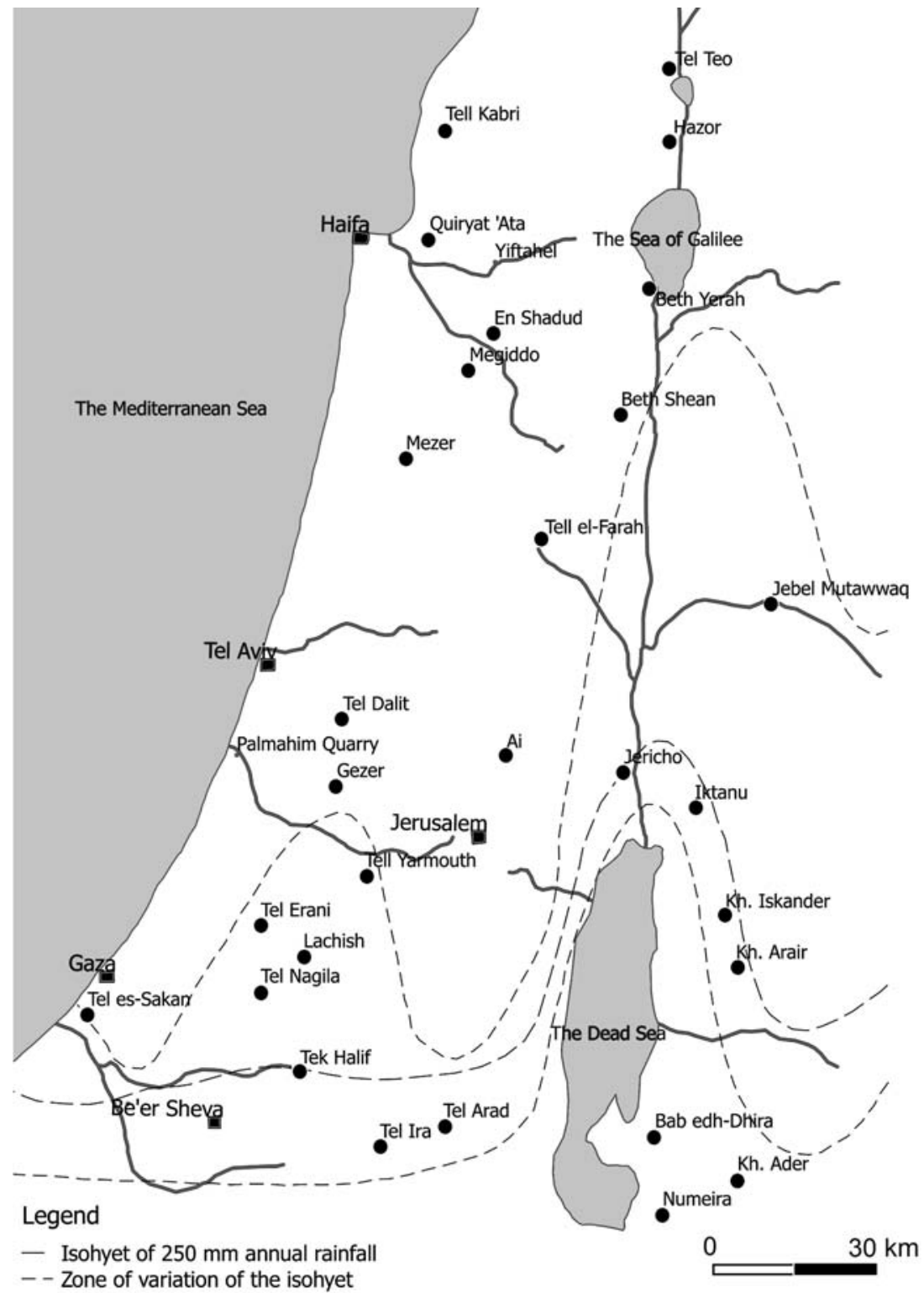

Fig. 4. Southern Levant - cities of the Early and Intermediate Bronze Age; the isohyet $250 \mathrm{~mm}$ is a theoretical limit of rain farming after Sebag (2005).

\section{REFERENCES}

Bar-Matthews M., Ayalon A., Kaufman, A. 1997. Late Quaternary paleoclimate in the eastern Mediterranean region from stable isotope analysis of speleothems at Soreq Cave, Israel. Quat. Res. 47, 155-168.

Bar-Matthews M., Ayalon A. 2011. Mid-Holocene climate variations revealed by high-resolution speleothem records from Soreq Cave, Israel and their correlation with cultural change. The Holocene 21(1) 163-171.

Bárta M. 2010. Borderland Dynamics in the Era of the Pyramid Builders in Egypt. In: Zartman I.W. (Ed.), Understanding Life in the Borderlands - Boundaries in Depth and in Motion, 21-39. University of Georgia Press, Athens, Georgia.

Berglund B.E., Ralska-Jasiewiczowa M. (Eds) 2003. Handbook of Holocene Palaeoecology and Palaeohydrology. The Blackburn Press, New Jersey.

Bieniada M.E. 2006. Between Canaan and Israel - The Genesis of the People of The Bible from Archaeological Perspective.
Pultusk (in Polish with English Summary).

Bond G., Showers W., Cheseby M., Lotti R., Almasi P., deMenocal P., Priore P., Cullen H., Hajdas I., Bonani G. 1997. A Pervasive Millennial-Scale Cycle in North Atlantic Holocene and Glacial Climates. Science 278 (5341), 1257-1266.

Boserup E., 1965. The conditions of agricultural growth: the economics of agrarian change under population pressure. London, Allen \& Unwin.

Bouzek J., 1982. Climatic Changes and central European History. In: Harding A. (Ed.), Climatic Change in later Prehistory, 179-191. Edinburg, Edinburg University Press.

Brooks N. 2006. Cultural responses to aridity in the Middle Holocene and increased social complexity. Quaternary International 151 (1), 29-49.

Cleveland R. 1960. The Excavations of the Conway High Place (Petra) and Soundings at Khirbet Ader. Annual of the American Schools of the Oriental Research, 34-35. New Haven, CT, American Schools of the Oriental Research.

deMenocal P.B. 2000. North Atlantic influence on Tigris-Euphra- 
tes streamflow. International Journal of Climatology 20 (8), $853-863$.

deMenocal P.B. 2001. Cultural responses to climate change during the Late Holocene. Science 292, 667-673.

Dever W.G. 1995. Social Structure in the Early Bronze IV Period in Palestine. Chapter. In Levy T.E. (Ed.), The Archaeology of Society in the Holy Land. Leicester University Press, LondonWashington.

Finlayson, B., Lovell, J., Smith, S., Mithen, S. 2011. The Archaeology of Water Managment in the Jordan Valley from the Epipalaeolithic to the Nabataean, 21,000 BP (19,000 BC) to AD 106. In: Mithen, S., Black, E. (Eds.), Water, Life and Civilisation: Climate, Environment and Society in the Jordan Valley. International Hydrology Series. Cambridge University Press.

Frumkin A., Elitzur Y. 2001. Historic Dead Sea Level Fluctuations Calibrated with Geological and Archaeological Evidence. Quaternary Research 57, 334-342.

Goldreich Y. 2003. The Climate of Israel. Observation, Research and Application. Springer Science+Business Media, LLC, New York.

Gophna, R. 1992. The intermediate Bronze Age. In: Ben-Tor A. (Ed.), The Archaeology of Ancient Israel, 126-158. Yale University Press, New Haven - London.

Issar, A.S., Zohar, M., 2007. Climate Change. Environment and History of the Near East. Springe, Berlin - Heidelberg - New York.

Kennett D.J., Kennett J.P. 2007. Influence of Holocene marine transgression and climate change on cultural evolution in southern Mesopotamia. In: Anderson D.G., Maasch K.A. and Sandweiss D.H. (Eds), Climate change and cultural dynamics: A Global Perspective on Mid-Holocene Transitions, 229-264. Elsevier.

Kuhrt A. 1995. The Ancient Near East ca. 3000-3300 BC. Routledge, London - New York.

Laughlin J.C.H. 2000. Approaching the Ancient World, Archaeology and the Bible. Routledge, London.

Malthus T.R., 1826. An Essay on the Principle of Population. Or a View of Its Past and Present Effects on Human Happiness; with an Inquiry Into Our Prospects Respecting the Future Removal or Mitigation of the Evils which It Occasions, $6^{\text {th }}$ edition. London, John Murray.

Mieroop M. van de 2007. A History of the Ancient Near East, ca. 3000-3230 BC. Second Edition, Blackwell History of the Ancient World, Malden, Blackwell.

Neev D., Emery K.O. 1967. The Dead Sea, deposital processes and environments of evaporates. Geological Survey of Israel Bulletin 41, 147pp.

Olávarri, E. 1969. Fouilles à 'Aro'er sur l'Arnon. Revue Biblique $76,230-259$.

Orni E., Efrat E. 1980. Geography of Israel. Israel Universities Press, Jerusalem.

Parr P. 1960. Excavations at Khirbet Iskander. Annual of the department of Antiquities in Jordan 4-6, 128-133.
Pitman M.G., Läuchli A. (Eds.) 2002. Global Impact of Salinity and Agricultural Ecosystems. In Salinity: Environment - Plants Molecules, 3-20. Springer 3-20.

Prag K. 1974. The Intermediate Early Bronze-Middle Bronze Age: An Interpretation of the Evidence from Transjordan, Syria, and Lebanon. Levant 6, 69-116.

Redman Ch.L. 1999. Human Impact on ancient environments. The University of Arizona Press.

Richard S. 1980. Toward a Consensus of Opinion on the End of the Early Bronze Age in Palestine-Transjordan. Bulletin of the American Schools of Oriental Research 237, 5-34.

Richard S. 1986. Excavations at Khirbet Iskander, Jordan: A Glimpse at Settled Life During the "Dark Age" in Palestinian Archaeology. Expedition 28, 3-12.

Richard S. 1987. The Early Bronze. The Rise and Collapse of Urbanism. Biblical Archaeologist 50, 22-43.

Rothman M.S. (Ed) 2001. Uruk Mesopotamia and Its Neighbours, Cross-Cultural Interactions in the Era of State Formation. School of American Research Advanced Seminar Series, School of American Research Press, Santa Fe, New Mexico.

Sebag D. 2005. The Early Bronze Age Dwellings in the Southern Levant. Bulletin du Centre de Recerche Français à Jérusalem $16,222-235$.

Shaw I. (Ed.) 2000. The Oxford History of Ancient Egypt. Oxford Univ. Press.

Stanley, J.-D., Krom, M. D., Cliff, R. A. and Woodward, J. C. (2003), Short contribution: Nile flow failure at the end of the Old Kingdom, Egypt: Strontium isotopic and petrologic evidence. Geoarchaeology, 18: 395-402, doi: 10.1002/gea.10065

Stern E. (Ed.), 1993. The New Encyclopaedia of Archaeological Excavations in the Holy Land. Jerusalem.

Walker M.J.C., Berkelhammer M., Bjorck S., Cwynard L.C., Fisher A. Long J., Lowe J, Newnham R.M., Rasmussen O., and Weiss H., 2012. Formal subdivision of the Holocene Series/Epoch: a Discussion Paper by a Working Group of INTIMATE (Integration of ice-core, marine and terrestrial records)

and the Subcommission on Quaternary Stratigraphy (International Commission on Stratigraphy). Jourmal of Quaternary Science, 27 (7) 649-659.

Weiss H. 2012. Altered trajectories: the Intermediate Bronze Age in Syria and Lebanon 2200-1900 BCE. In: Killebrew A, Steiner M. (Eds.), Oxford Handbook of the Archaeology of the Levant. Oxford University Press, Oxford.

Weiss H., Courty M.-A., Wetterstrom W., Guichard F., Senior L., Meadow R., Curnow A. 1993. The genesis and collapse of Third Millennium North Mesopotamian Civilisation. Science 261, 995-1004.

Welc F, Marks L. 2013. Climate change at the end of the Old Kingdom in Egypt around 4200 BP: New geoarchaeological evidence. Quaternary International 324, 124-133.

Welc F, Marks L., 2014. Sub-pluvial Saqqara and its possible impact on ancient Egyptian civilization in the Old Kingdom Period (4600-4100 yrs. BP). Geophysical Research Abstracts 16, EGU214, 2076. 